\title{
PENGARUH PENGALAMAN MENGAJAR, ETOS KERJA DAN MOTIVASI MENGAJAR TERHADAP KINERJA GURU SMK NEGERI 1 SIBOLGA
}

\author{
${ }^{1}$ Dahlia Elisah Ritonga, ${ }^{2}$ Rosmida Pohan, ${ }^{3}$ Romauli Sianturi, ${ }^{4}$ Ganda Roy Hutagalung, ${ }^{5}$ Gibson H.Purba \\ $1,2,3,4,5$ Universitas Islam Sumatera Utara \\ 11 dahlia.elisah@gmail.com, ${ }^{2}$ rosmida.pohan@gmail.com, ${ }^{3}$ romauli.sianturi@gmail.com, ${ }^{4}$ ganda.roy@gmail.com, \\ ${ }^{5}$ Gibson.purba@gmail.com
}

\begin{abstract}
The purpose of this research was to determine and analyze the influence of teaching experience, work ethics and teaching motivation on the performance of teachers of SMK Negeri 1 Sibolga, both partially and simultaneously. The sample in this research were all employees, amounting to 55 teachers. Determination of the number of samples using a saturated sample (census). The analysis technique used is descriptive analysis method and multiple linear regression analysis with SPSS 20.00 for windows. The results showed that : 1) Teaching Experience had a positive and significant effect on the performance of teachers of SMK Negeri 1 Sibolga, where the value of $t_{\text {count }}(2.161)>$ $t_{\text {table }}(1.675)$ and the probability level of $\left.0.035<0.05 ; 2\right)$ Work Ethics has a positive and significant effect on the performance of teachers of SMK Negeri 1 Sibolga, where the value of $t_{\text {count }}(2.225)>$ $t_{\text {table }}(1.675)$ and probability value of $0.031<0.05$; 3) Teaching Motivation has a positive and significant effect on the performance of teachers of SMK Negeri 1 Sibolga, where the value $t_{\text {count }}$ $(6.341)>t_{\text {table }}(1.675)$ and probability value of $0.000<0.05$; 4) Teaching experience, work ethic and teaching motivation are positive and significant to the performance of teachers of SMK Negeri 1 Sibolga, where the value of $F_{\text {count }}(24,977)>F_{\text {table }}(2,786)$ and probability $0,000<0.05$. Teaching experience, work ethic and teaching motivation explain its influence on teacher performance by $57.1 \%$, while the remaining $42.9 \%$ is requested by other variables not examined in this research.
\end{abstract}

Keywords : Teaching Experience, Work Ethics, Teaching Motivation, Performance of Teachers.

ABSTRAK : Tujuan penelitian ini adalah untuk mengetahui dan menganalisis pengaruh pengalaman mengajar, etos kerja dan motivasi mengajar terhadap kinerja guru SMK Negeri 1 Sibolga baik secara parsial dan simultan. Sampel dalam penelitian ini adalah seluruh guru yang berjumlah 55 orang. Penentuan jumlah sampel menggunakan sampel jenuh (sensus). Teknik analisis yang digunakan adalah metode analisis deskriptif dan analisis regresi linear berganda dengan program SPSS 20.00 for windows. Hasil penelitian menunjukkan bahwa: Pengalaman mengajar berpengaruh positif dan signifikan terhadap kinerja guru SMK Negeri 1 Sibolga, dimana nilai $t_{\text {hitung }}(2,161)>t_{\text {tabel }}(1,675)$ dan tingkat probabilitas sebesar 0,035 $<0,05$;2) Etos kerja berpengaruh positif dan signifikan terhadap kinerja guru SMK Negeri 1 Sibolga, dimana diperoleh nilai $t_{\text {hitung }}(2,225)>t_{\text {tabel }}(1,675)$ dan tingkat probabilitas sebesar 0,031 < 0,05; 3) Motivasi mengajar berpengaruh positif dan signifikan terhadap kinerja guru SMK Negeri 1 Sibolga, dimana diperoleh nilai $t_{\text {hitung }}(6,341)>t_{\text {tabel }}(1,675)$ dan tingkat probabilitas sebesar $\left.0,000<0,05 ; 4\right)$ Pengalamana mengajar, etos kerja dan motivasi mengajar berpengaruh positif dan signifikan terhadap kinerja guru SMK Negeri 1 Sibolga, dimana diperoleh nilai $F_{\text {hitung }}(24,977)>F_{\text {tabel }}$ $(2,786)$ dan probabilitas 0,000 < 0,05. Pengalaman mengajar, etos kerja dan motivasi mengajar mampu menjelaskan pengaruhnya terhadap kinerja guru sebesar 57,1\%, sedangkan sisanya 42,9\% dijelaskan oleh variabel lain yang tidak dikaji dalam penelitian ini.

Kata kunci : Pengalaman Mengajar, Etos Kerja, Motivasi Mengajar, Kinerja Guru. 


\section{Pendahuluan}

Sekolah Menengah Kejuruan (SMK) merupakan salah satu bentuk satuan pendidikan formal yang menyelenggarakan pendidikan kejuruan pada jenjang pendidikan menengah (Undang-Undang Sisdiknas Nomor 20 Tahun 2003). Pendidikan menengah kejuruan mengutamakan penyiapan siswa untuk memasuki lapangan kerja serta mengembangkan sikap profesional. Sesuai dengan bentuknya, sekolah menengah kejuruan menyelenggarakan program-program pendidikan yang disesuaikan dengan jenis-jenis lapangan kerja (Peraturan Pemerintah Nomor 29 Tahun 1990). Berdasarkan definisi diatas, Sekolah Menengah Kejuruan (SMK) merupakan salah satu lembaga pendidikan formal yang bertujuan mempersiapkan para lulusan untuk masuk ke dunia kerja.

Untuk mewujudkan hal tersebut diperlukan adanya komponen yang mendukung, yang salah satunya adalah kinerja guru yang profesional. Kinerja guru sebagai kunci keberhasilan pendidikan, karena keberadaan guru sangat berpengaruh terhadap semua sumber daya pendidikan yang ada. Berbagai sumber daya pendidikan seperti, sarana dan prasarana, biaya, teknologi, informasi, siswa dan orang tua siswa dapat berfungsi dengan baik apabila guru memiliki kemampuan yang baik pula dalam menggunakan semua sumber daya yang ada. Menurut Uzer Usman (2014:15), guru profesional adalah orang yang memiliki kemampuan dan keahlian khusus dalam bidang keguruan sehingga ia mampu melakukan tugas dan fungsinya sebagai guru dengan kemampuan maksimal. Sedangkan menurut Rice dan Bishoprick, guru profesional adalah guru yang mampu mengelola dirinya sendiri dalam melaksanakan tugas seharihari. Seorang guru profesional harus memiliki beberapa kompetensi, yaitu kompetensi intelektul, kompetensi fisik, kompetensi pribadi, kompetensi sosial dan kompetensi spiritual.

Pengalaman guru dalam mengajar dan melaksanakan tugas sebagai pendidik merupakan suatu hal yang berharga. Kinerja profesi guru diduga dipengaruhi oleh pengalaman mengajar guru. Wibowo (2014:284) mengemukakan bahwa pengalaman merupakan elemen yang perlu, tetapi untuk menjadi ahli tidak cukup dengan pengalaman. Namun demikian, pengalaman merupakan aspek lain kompetensi yang dapat berubah dengan perjalanan waktu dan perubahan lingkungan. Menurut Uno (2013:17) pada dasarnya perubahan perilaku yang dapat ditunjukkan peserta didik dipengaruhi oleh latar belakang pendidikan dan pengalaman yang dimiliki oleh seorang guru. Semakin berpengalaman guru dalam mengajar semakin luas materi pelajaran yang dikuasai sehingga memungkinkan guru untuk meningkatkan kompetensi profesionalnya. Widoyoko (dalam Aulia, 2015:4) memaparkan bahwa pengalaman mengajar pada hakekatnya merupakan rangkuman dari pemahaman seseorang terhadap hal-hal yang dialami dalam mengajar, sehingga hal-hal yang dialami tersebut telah dikuasinya, baik tentang pengetahuan, ketrampilan maupun nilai-nilai yang menyatu padanya.

Selain pengalaman mengajar, diduga etos kerja guru juga memepengaruhi tingkat kinerja guru. Etos kerja perlu dimiliki seorang guru agar dapat mencapai standar yang telah ditetapkan, karena dengan ini guru mempunyai semangat yang amat kuat untuk mengerjakan tugasnya secara optimal. Seperti yang dikemukakan Mohamad Surya (2014:38) salah satu ciri profil guru yang diperkirakan sesuai dengan tuntutan masa depan menghadapi abad 21 adalah guru yang memiliki etos kerja yang kuat. Etos kerja merupakan kondisi internal yang mendorong dan mengendalikan perilaku kearah terwujudnya kualitas kerja yang ideal (Kartini:2011). Setiap organisasi yang selalu ingin maju akan melibatkan anggota untuk meningkatkan mutu kerjanya, diantaranya setiap organisasi harus memiliki etos kerja, begitupun dengan guru sebagai anggota organisasi sekolah. Seperti yang diungkapkan Sinamo (2015:249) etos kerja adalah syarat utama bagi semua upaya peningkatan kualitas tenaga kerja atau SDM, baik pada level individual, organisasional, maupun sosial. Hasil penelitian penelitian Widoyoko (2015) menunjukkan bahwa etos kerja memberikan sumbangan positif terhadap kompetensi mengajar guru sebesar $16,59 \%$. Sejalan dengan hasil penelitian oleh Sudjana (2013:60) etos kerja signifikan terhadap pengembangan kinerja guru dan memberikan sumbangan efektif sebesar 12,16 \% terhadap kinerja guru SMP di Kecamatan Ubud. Sedangkan hasil penelitian Heryanto (2014) etos kerja guru berpengaruh secara signifikan terhadap efektivitas proses belajar mengajar sebesar $42,5 \%$.

Dalam kajian teori Robbins (2014:218), untuk menganalisis dimensi kinerja merupakan fungsi dari interaksi antara kemampuan dan 
motivasi. Persamaan ini menggambarkan bahwa performance merupakan fungsi dari motivasi dan kemampuan. Semakin tinggi motivasi dan kemampuan seorang, maka akan semakin tinggi pula kinerjanya. Namun demikian dalam teori ditambahkan kesempatan untuk berkinerja, karena mengingat seorang individu mungkin bersedia dan mampu namun ada rintangan yang mengendalai kinerja. Tingkat-tingkat kinerja yang tinggi sebagian merupakan fungsi dan tidak adanya rintangan yang mengendalai karyawan itu. Dari teori Robbins tersebut dapat disimpulkan bahwa salah satu faktor yang mempengaruhi kinerja guru adalah motivasi.

Pada kenyataan di lapangan menunjukkan, bahwa kinerja guru belum optimal. Sehingga persoalan kinerja guru menjadi perhatian yang cukup serius oleh Dinas Pendidikan Kota Sibolga. Hal ini dibuktikan dengan dilakukannya secara rutin supervisi ke setiap SMK, diberikannya kesempatan yang cukup luas bagi guru yang akan studi lanjut, penyelenggaraan pendidikan dan pelatihan bagi para guru, seminar dan sebagainya. Selain itu, berdasarkan hasil survei pendahuluan di sekolah yang akan di jadikan objek penelitian, peneliti menemukan data jumlah guru pengampu mata belum sesuai antara pendidikan dengan bidang pekerjaan. Dan untuk peraturan jam mengajar yang telah ditetapkan setiap guru mengajar $24 \mathrm{jam} / \mathrm{ming} g u$, yang idealnya adalah $18 \mathrm{jam} / \mathrm{minggu}$ tatap muka, dalam kenyataannya sebanyak $74,2 \%$ guru mengajar melebihi dari standar yang telah ditetapkan.

\subsection{Batasan Masalah}

Batasan masalah dalam penelitian ini meliputi variabel independen yang terdiri dari pengalaman mengajar guru, etos kerja dan motivasi guru serta variabel dependen yaitu kinerja guru.

\subsection{Hioptesis}

Menurut Sugiyono (2014:93) hipotesis adalah jawaban sementara terhadap rumusan masalah-masalah penelitian, oleh karena itu rumusan masalah penelitian biasanya disusun dalam bentuk kalimat pernyataan. Berdasarkan rumusan masalah yang telah diuraikan, maka peneliti merumuskan hipotesis sebagai berikut :

1) Pengalaman mengajar berpengaruh signifikan terhadap kinerja guru SMK Negeri 1 Sibolga.
2) Etos kerja berpengaruh signifikan terhadap kinerja guru SMK Negeri 1 Sibolga.

3) Motivasi mengajar berpengaruh signifikan terhadap kinerja guru SMK Negeri 1 Sibolga.

4) Pengalaman mengajar, etos kerja dan motivasi mengajar berpengaruh signifikan terhadap kinerja guru SMK Negeri 1 Sibolga.

\subsection{Tujuan Penelitian}

Berdasarkan permasalahan diatas maka tujuan penelitian adalah :

1) Untuk mengetahui dan menganalisis pengaruh pengalaman mengajar terhadap kinerja guru SMK Negeri 1 Sibolga.

2) Untuk mengetahui dan menganalisis pengaruh etos kerja terhadap kinerja guru SMK Negeri 1 Sibolga.

3) Untuk mengetahui dan menganalisis pengaruh motivasi mengajar terhadap kinerja guru SMK Negeri 1 Sibolga.

4) Untuk mengetahui dan menganalisis pengaruh pengalaman mengajar, etos kerja dan motivasi mengajar terhadap kinerja guru SMK Negeri 1 Sibolga.

\section{Metode Penelitian}

\subsection{Populasi}

Menurut Sugiyono (2016:80) Populasi adalah wilayah generalisasi yang terdiri atas obyek/subjek yang mempunyai kualitas dan karakteristik tertentu yang ditetapkan oleh peneliti untuk dipelajari dan kemudian ditarik kesimpulannya. Arikunto (2014:173) menjelaskan populasi adalah keseluruhan subjek penelitian. Apabila seseorang ingin meneliti semua elemen yang ada dalam wilayah penelitian, maka penelitiannya merupakan penelitian populasi. Populasi pada penelitian ini adalah seluruh guru SMK Negeri 1 Sibolga yang berjumlah 55 orang.

Tabel 1. Kerangka Populasi

\begin{tabular}{clcc}
\hline No & Keterangan & Jumlah & Persentase \\
\hline 1. & Guru PNS & 53 & $96,4 \%$ \\
2. & Guru Honorer & 2 & $5,6 \%$ \\
& Jumlah & $\mathbf{5 5}$ & $\mathbf{1 0 0 , 0 \%}$ \\
\hline
\end{tabular}

\subsection{Sampel}

Sampel adalah bagian dari jumlah dan karakteristik yang dimiliki oleh populasi. Menurut Arikunto (2014:22) apabila subjek dari suatu populasi yang akan diteliti kurang dari 100, maka lebih baik diambil semua sehingga penelitiannya merupakan penelitian populasi, 
selanjutnya apabila subjeknya lebih dari 100 , maka diambil 10\% - 15\% atau 20\% - 25\%. Apabila objek kurang dari 100 orang lebih baik diambil semua, sehingga penelitian merupakan penelitian populasi. Dengan demikian sampel yang diambil adalah keseluruhan dari jumlah populasi sebanyak 55 orang.

\subsection{Uji Normalitas}

\subsubsection{Uji Normalitas P Plot}

Uji normalitas dengan pendekatan grafik. $P P$ plot akan membentuk plot antara nilai-nilai teoritis (sumbu $\mathrm{X}$ ) melawan nilai-nilai yang didapat dari sampel (sumbu Y). Apabila plot keduanya berbentuk linier (dapat didekati oleh garis lurus), maka hal ini merupakan indikasi bahwa residual menyebar normal.

\subsubsection{Uji Kolmogorov-Smirnov}

Tabel 2 Hasil Uji Kolmogorov-Smirnov

One-Sample Kolmogorov-Smirnov Test

\begin{tabular}{|ll|r|}
\hline & & $\begin{array}{c}\text { Unstandardize } \\
\text { d Residual }\end{array}$ \\
\hline $\mathrm{N}$ & & 55 \\
Normal Parameters ${ }^{\mathrm{a}, \mathrm{b}}$ & Mean & $0 \mathrm{E}-7$ \\
& Std. Deviation & 1.08768159 \\
Most Extreme & Absolute & .167 \\
Differences & Positive & .167 \\
Kolmogorov-Smirnov Z & Negative & -.099 \\
Asymp. Sig. (2-tailed) & & 1.241 \\
a. Test distribution is Normal. & .092 \\
b. Calculated from data. & \\
\end{tabular}

Dari tabel 2 terlihat bahwa nilai Asymp. Sig. (2-tailed) adalah 0,092 > 0,05. Dapat disimpulkan bahwa data residual berdistribusi normal. Nilai Kolmogorov-Smirnov Z dari tabel 5.10 yaitu $1,241<1,97$ berarti tidak ada perbedaan antara distribusi teoritik dan distribusi empirik atau dengan kata lain data dikatakan normal.

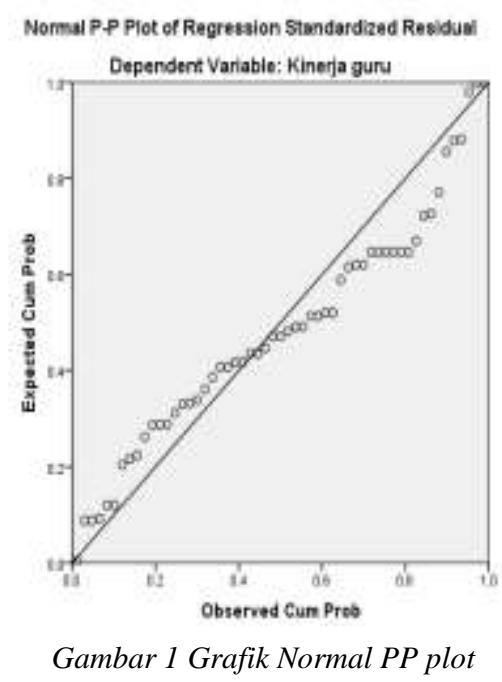

Pada gambar 1 grafik normal $p p$ plot terlihat titik yang mengikuti data di sepanjang garis diagonal. Hal ini berarti data berdistribusi normal.

\subsection{Uji Multikolinearitas}

Untuk mengetahui ada tidaknya gejala multikolinearitas dapat dilihat dari besarnya nilai tolerance dan VIF (Variance Inflation Factor) melalui program SPSS. Tolerance mengukur variabilitas variabel terpilih yang tidak dijelaskan oleh variabel independen lainnya. Nilai umum yang bisa dipakai adalah nilai Tolerance $>0,1$ atau nilai VIF $<10$, maka tidak terjadi multikolinearitas. Hasil pengolahan dapat dilihat pada Tabel 5.12: 
Tabel 3. Hasil Uji Multikolinearitas

Coefficients $^{\mathrm{a}}$

\begin{tabular}{|c|c|c|c|c|c|c|c|}
\hline \multirow[t]{2}{*}{ Model } & \multicolumn{2}{|c|}{$\begin{array}{c}\text { Unstandardized } \\
\text { Coefficients }\end{array}$} & $\begin{array}{l}\text { Standardized } \\
\text { Coefficients }\end{array}$ & \multirow[t]{2}{*}{$\mathrm{t}$} & \multirow[t]{2}{*}{ Sig. } & \multicolumn{2}{|c|}{$\begin{array}{l}\text { Collinearity } \\
\text { Statistics }\end{array}$} \\
\hline & B & Std. Error & Beta & & & Tolerance & VIF \\
\hline (Constant) & 2.087 & 2.430 & & .859 & .394 & & \\
\hline $\begin{array}{l}\text { Pengalaman } \\
\text { mengajar }\end{array}$ & .166 & .077 & 205 & 2.161 & .035 & .885 & 1.129 \\
\hline Etos kerja & .150 & .067 & .206 & 2.225 & .031 & .925 & 1.082 \\
\hline Motivasi mengajar & .715 & .113 & .602 & 6.341 & .000 & .882 & 1.134 \\
\hline
\end{tabular}

a. Dependent Variable: Kinerja guru

Pada Tabel 3, diketahui bahwa pada variabel Pengalaman Mengajar $\left(\mathrm{X}_{1}\right)$ nilai Tolerance $(0,885)>(0,1)$ dan VIF $(1,129)<$ (10), variabel etos kerja $\left(\mathrm{X}_{2}\right)$ nilai Tolerance $(0,925)>(0,1)$ dan VIF $(1,082)<(10)$ dan variabel motivasi mengajar $\left(\mathrm{X}_{3}\right)$ nilai Tolerance $(0,882)>(0,1)$ dan VIF $(1,134)<(10)$, yang artinya tidak terjadi masalah multikolinearitas pada masing-masing variabel bebasnya.

\subsection{Uji Heteroskedastisitas}

\subsubsection{Pendekatan Grafik}

Heterokedastisitas dapat juga dilihat melalui gambar scatterplot. Gambar scatter plot dapat mengindikasi ada atau tidaknya gejala heterokedastisitas. Apabila grafik tidak membentuk pola yang jelas maka tidak mengalami gangguan heterokedastisitas.

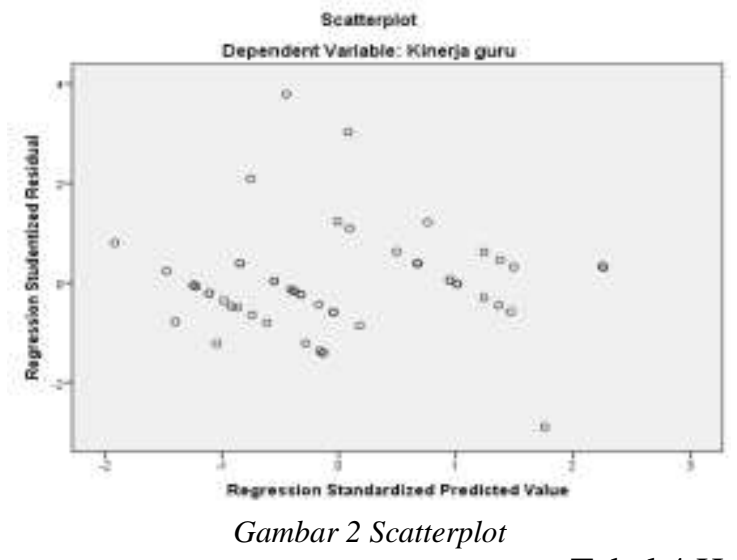

Gambar 2, menunjukkan bahwa penyebaran residual cenderung tidak teratur, terdapat titik-titik yang berpencar. Kesimpulan yang dapat diperoleh adalah tidak terdapat gejala heterokedastisitas, sehingga model regresi layak dipakai untuk memprediksi kinerja guru berdasarkan masukan variabel pengalaman mengajar, etos kerja dan motivasi mengajar.

\subsubsection{Uji Glejser}

Kriteria pengambilan keputusannya adalah sebagai berikut :

a) Jika nilai signifikansi $>0,05$, maka tidak mengalami gangguan heterokedastisitas.

b) Jika nilai signifikansi < 0,05, maka mengalami gangguan heterokedastisitas.

Tabel 4 Hasil Uji Glejser

Coefficients $^{\text {a }}$

\begin{tabular}{|c|c|c|c|c|c|}
\hline \multirow[t]{2}{*}{$\longdiv { \text { Model } }$} & \multicolumn{2}{|c|}{$\begin{array}{c}\text { Unstandardized } \\
\text { Coefficients }\end{array}$} & \multirow{2}{*}{\begin{tabular}{|c|}
$\begin{array}{c}\text { Standardized } \\
\text { Coefficients }\end{array}$ \\
Beta
\end{tabular}} & \multirow[t]{2}{*}{$\mathrm{t}$} & \multirow[t]{2}{*}{ Sig. } \\
\hline & B & Std. Error & & & \\
\hline (Constant) & -.802 & 1.625 & & -.493 & .624 \\
\hline $\begin{array}{l}\text { Pengalaman } \\
\text { mengajar }\end{array}$ & .078 & .051 & .204 & 1.521 & .134 \\
\hline Etos kerja & .115 & .045 & .334 & 2.543 & .084 \\
\hline Motivasi mengajar & -.164 & .075 & -.293 & -2.180 & .074 \\
\hline
\end{tabular}


Pada Tabel 4, menunjukkan tidak adanya masalah heterokedastisitas, dimana hasil uji signifikan variabel Pengalaman Mengajar $\left(\mathrm{X}_{1}\right)$ $0,134>0,05$, variabel etos kerja $\left(X_{2}\right) 0,084>$ 0,05 , dan variabel motivasi mengajar $\left(X_{3}\right) 0,074$ $>0,05$.

\section{Hasil Pengujian Hipotesis}

Tabel 5. Hasil Analisis Regresi Linear Berganda

Coefficients $^{\mathrm{a}}$

\begin{tabular}{|c|c|c|c|c|c|}
\hline \multirow[t]{2}{*}{ Model } & \multicolumn{2}{|c|}{$\begin{array}{l}\text { Unstandardized } \\
\text { Coefficients }\end{array}$} & \multirow{2}{*}{$\begin{array}{c}\begin{array}{c}\text { Standardize } \\
\mathrm{d} \\
\text { Coefficients }\end{array} \\
\text { Beta }\end{array}$} & \multirow[t]{2}{*}{$\mathrm{t}$} & \multirow[t]{2}{*}{ Sig. } \\
\hline & $\mathrm{B}$ & Std. Error & & & \\
\hline (Constant) & 2.087 & 2.430 & & .859 & .394 \\
\hline $1 \begin{array}{l}\text { Pengalaman } \\
\text { mengajar }\end{array}$ & .166 & .077 & 205 & 2.161 & .035 \\
\hline Etos kerja & .150 & .067 & 206 & 2.225 & .031 \\
\hline Motivasi mengajar & .715 & .113 & .602 & 6.341 & .000 \\
\hline
\end{tabular}

a. Dependent Variable: Kinerja guru

Persamaan regresi linier berganda dapat diperoleh dari Tabel 5, sebagai berikut :

$Y=2,087+0,166 X_{1}+0,150 X_{2}+0,715 X_{3}+e$

Interpretasi model tersebut sebagai berikut

1) Nilai konstanta sebesar 2,087 menunjukkan bahwa jika variabel pengalaman mengajar $\left(\mathrm{X}_{1}\right)$, etos kerja $\left(\mathrm{X}_{2}\right)$ dan motivasi mengajar $\left(X_{3}\right)$ dianggap tetap, tidak mengalami perubahan atau penurunan dalam penelitian ini maka nilai kinerja guru $(\mathrm{Y})$ sebesar 2,087 . mengajar $\left(X_{1}\right)$ sebesar 0,166 . Ini bermakna bahwa jika variabel pengalaman mengajar $\left(\mathrm{X}_{1}\right)$ mengalami kenaikan sebesar satu satuan, maka akan menyebabkan kenaikan kinerja guru (Y) sebesar 0,166, dengan menganggap variabel lain konstan.

3) Koefisien regresi variabel etos kerja $\left(X_{2}\right)$ sebesar 0,150. Ini bermakna bahwa jika variabel etos kerja mengalami kenaikan sebesar satu satuan, maka akan menyebabkan kenaikan kinerja guru $(\mathrm{Y})$ sebesar 0,150 , dengan menganggap variabel lain konstan.

4) Koefisien regresi variabel motivasi mengajar $\left(\mathrm{X}_{3}\right)$ sebesar 0,715. Ini bermakna bahwa jika variabel motivasi mengajar mengalami kenaikan sebesar satu satuan, maka akan menyebabkan kenaikan kinerja guru (Y) sebesar 0,715 , dengan menganggap variabel lain konstan.
2) Koefisien regresi variabel pengalaman

\subsection{Hasil Analisis Regresi Linear Berganda}

Analisis regresi linier berganda digunakan untuk mengetahui berapa besar pengaruh variabel bebas (pengalaman mengajar, etos kerja dan motivasi mengajar) terhadap variabel terikat (kinerja guru). Analisis dilakukan dengan menggunakan bantuan SPSS 20.0 for windows.
Pada persamaan tersebut dapat dilihat bahwa pengalaman mengajar, etos kerja dan motivasi mengajar memiliki kemampuan untuk mempengaruhi kinerja guru SMK Negeri 1 Sibolga. Pengalaman mengajar, etos kerja dan motivasi mengajar mempunyai koefisien regresi positif yang membuktikan kontibusinya terhadap kinerja guru SMK Negeri 1 Sibolga. Hal ini menunjukkan bahwa kinerja guru SMK Negeri 1 Sibolga dapat dipengaruhi oleh pengalaman mengajar, etos kerja dan motivasi mengajar.

\subsection{Uji Signifikansi Parsial (Uji t)}

Uji t menentukan seberapa besar pengaruh pengalaman mengajar $\left(\mathrm{X}_{1}\right)$, etos kerja $\left(\mathrm{X}_{2}\right)$ dan motivasi mengajar $\left(\mathrm{X}_{3}\right)$ secara parsial terhadap kinerja guru (Y) SMK Negeri 1 Sibolga.

- H0 : $b_{1}=b_{2}=b_{3}=0$, artinya secara parsial tidak terdapat pengaruh yang positif dan signifikan antara variabel pengalaman mengajar, etos kerja dan motivasi mengajar terhadap kinerja guru.

- Ha : $b_{1} \neq b_{2} \neq b_{3} \neq 0$, artinya secara parsial terdapat pengaruh yang positif dan signifikan antara variabel pengalaman mengajar, etos kerja dan motivasi mengajar terhadap kinerja guru.

Kriteria pengambilan keputusan :

- H0 diterima jika $\mathrm{t}_{\text {hitung }}<\mathrm{t}_{\text {tabel }}$ pada $\alpha=5 \%$

- Ha diterima jika $t_{\text {hitung }}>t_{\text {tabel }}$ pada $\alpha=5 \%$ 
Tabel 6. Hasil Uji Parsial (Uji t)

Coefficients $^{\mathrm{a}}$

\begin{tabular}{|c|c|c|c|c|c|}
\hline \multirow[t]{2}{*}{ Model } & \multicolumn{2}{|c|}{$\begin{array}{l}\text { Unstandardized } \\
\text { Coefficients }\end{array}$} & \multirow{2}{*}{$\begin{array}{c}\begin{array}{c}\text { Standardize } \\
\mathrm{d} \\
\text { Coefficients }\end{array} \\
\text { Beta }\end{array}$} & \multirow[t]{2}{*}{$\mathrm{t}$} & \multirow[t]{2}{*}{ Sig. } \\
\hline & $\mathrm{B}$ & Std. Error & & & \\
\hline (Constant) & 2.087 & 2.430 & & .859 & .394 \\
\hline $\begin{array}{l}\text { Pengalaman } \\
\text { mengajar }\end{array}$ & .166 & .077 & .205 & 2.161 & .035 \\
\hline Etos kerja & .150 & .067 & 206 & 2.225 & .031 \\
\hline Motivasi mengajar & .715 & .113 & .602 & 6.341 & .000 \\
\hline
\end{tabular}

a. Dependent Variable: Kinerja guru

Dari tabel 6. hasil uji signifikan secara parsial dapat diambil kesimpulan yaitu :

1) Pengaruh Pengalaman Mengajar Terhadap Kinerja Guru.

Variabel pengalaman mengajar mempunyai angka signifikansi sebesar $0,035<0,05$. Artinya secara parsial pengalaman mengajar berpengaruh signifikan terhadap kinerja guru. Untuk melihat diterima atau ditolaknya sebuah hipotesis juga bisa dilakukan dengan membandingkan nilai $t_{\text {hitung }}$ dengan $t_{\text {tabel. }}$. Jika $t_{\text {hitung }}>t_{\text {tabel }}$, maka hipotesis diterima. Nilai $\mathrm{t}_{\text {hitung }}=2,161$ dan $\mathrm{t}_{\text {tabel }}$ untuk $\mathrm{df}=\mathrm{n}-\mathrm{k}=55-4=51$ dan signifikansi 0,05 dengan uji 2 arah adalah 1,675. Artinya, nilai $t_{\text {hitung }}(2,161)>t_{\text {tabel }}$ $(1,675)$, maka pengalaman mengajar berpengaruh positif dan signifikan terhadap kinerja guru SMK Negeri 1 Sibolga. Dengan demikian hipotesis dapat diterima.

2) Pengaruh Etos Kerja Terhadap Kinerja Guru.

Variabel etos kerja mempunyai angka signifikansi sebesar $0,031<0,05$. Artinya etos kerja secara parsial berpengaruh signifikan terhadap kinerja guru. Untuk melihat diterima atau ditolaknya sebuah hipotesis juga bisa dilakukan dengan membandingkan nilai $t_{\text {hitung }}$ dengan $t_{\text {tabel. }}$. Jika $t_{\text {hitung }}>t_{t a b e l}$, maka hipotesis diterima. Nilai $\mathrm{t}_{\text {hitung }}=2,225$ dan $\mathrm{t}_{\text {tabel }}$ untuk df $=\mathrm{n}-\mathrm{k}=55$ $-4=51$ dan signifikansi 0,05 dengan uji 2 arah adalah 1,675. Artinya, nilai $t_{\text {hitung }}$ $(2,225)>t_{\text {tabel }}(1,675)$, maka etos kerja berpengaruh positif dan signifikan terhadap kinerja guru SMK Negeri 1 Sibolga. Dengan demikian hipotesis dapat diterima.
3) Pengaruh Motivasi Mengajar Terhadap Kinerja Guru.

Variabel motivasi mengajar mempunyai angka signifikansi sebesar $0,000<0,05$. Artinya motivasi mengajar secara parsial berpengaruh signifikan terhadap kinerja guru. Untuk melihat diterima atau ditolaknya sebuah hipotesis juga bisa dilakukan dengan membandingkan nilai $t_{\text {hitung }}$ dengan $t_{\text {tabel. }}$. Jika $t_{\text {hitung }}>t_{\text {tabel }}$, maka hipotesis diterima. Nilai $\mathrm{t}_{\text {hitung }}=6,341$ dan $\mathrm{t}_{\text {tabel }}$ untuk $\mathrm{df}=\mathrm{n}-\mathrm{k}=55-4=51$ dan signifikansi 0,05 dengan uji 2 arah adalah 1,675. Artinya, nilai $t_{\text {hitung }}(6,341)>t_{\text {tabel }}$ $(1,675)$, maka motivasi mengajar berpengaruh positif dan signifikan terhadap kinerja guru SMK Negeri 1 Sibolga. Dengan demikian hipotesis dapat diterima.

\subsection{Uji Signifikansi Simultan (Uji F)}

Uji F pada dasarnya menunjukkan apakah semua variabel bebas yang dimasukkan dalam model mempunyai pengaruh secara bersamasama terhadap variabel terikat.

- H0 : $b_{1}=b_{2}=b_{3}=0$, artinya secara bersamasama tidak terdapat pengaruh yang positif dan signifikan antara variabel pengalaman mengajar, etos kerja dan motivasi mengajar terhadap kinerja guru.

- Ha $: b_{1} \neq b_{2} \neq b_{3} \neq 0$, artinya secara bersamasama terdapat pengaruh yang positif dan signifikan antara variabel pengalaman mengajar, etos kerja dan motivasi mengajar terhadap kinerja guru.

Kriteria pengambilan keputusan :

- H0 diterima jika $F_{\text {hitung }}<\mathrm{F}_{\text {tabel }}$ pada $\alpha=5 \%$.

- Ha diterima jika $F_{\text {hitung }}>F_{\text {tabel }}$ pada $\alpha=5 \%$. 
Tabel 7 Hasil Uji Simultan (Uji F)

ANOVA $^{\mathrm{a}}$

\begin{tabular}{|c|c|c|c|c|c|c|}
\hline \multicolumn{2}{|c|}{ Model } & $\begin{array}{l}\text { Sum of } \\
\text { Squares }\end{array}$ & $\mathrm{df}$ & Mean Square & $\mathrm{F}$ & Sig. \\
\hline \multirow{3}{*}{1} & Regression & 93.861 & 3 & 31.287 & 24.977 & $.000^{\mathrm{b}}$ \\
\hline & Residual & 63.885 & 51 & 1.253 & & \\
\hline & Total & 157.745 & 54 & & & \\
\hline
\end{tabular}

b. Predictors: (Constant), Motivasi mengajar, Etos kerja, Pengalaman mengajar

Melalui uji ANOVA atau F-test pada Tabel 5.14, diperoleh nilai $F_{\text {hitung }}$ sebesar 24,977 dengan tingkat signifikansi 0,000 . Selanjutnya dilakukan pembandingan $F_{\text {hitung }}$ dengan $F_{\text {tabel }}$, dimana nilai $F_{\text {tabel }}$ yang digunakan adalah $F_{\text {tabel }}$ untuk df(3:51) yaitu 2,786. Berdasarkan hasil tersebut, maka diperoleh nilai $\mathrm{F}_{\text {hitung }}(24,977)>$ $\mathrm{F}_{\text {tabel }}(2,786)$ pada taraf signifikan $0,00<0,05$. Artinya bahwa secara simultan pengalaman mengajar, etos kerja dan motivasi mengajar berpengaruh positif dan signifikan terhadap kinerja guru SMK Negeri 1 Sibolga. Dengan demikian hipotesis dapat diterima.

\subsection{Hasil Uji Determinan}

Koefisien determinasi $\left(R^{2}\right)$ pada intinya mengukur seberapa besar kemampuan model dalam menerangkan variabel terikat. Jika $R^{2}$ semakin besar (mendekati satu), maka dapat dikatakan bahwa hubungan variabel bebas $\left(\mathrm{X}_{1}\right.$, $\mathrm{X}_{2}$ ) adalah besar terhadap variabel terikat $(\mathrm{Y})$. Hal ini berarti model yang digunakan semakin kuat untuk menerangkan hubungan variabel bebas yang diteliti terhadap variabel terikat. Sebaliknya, jika $R^{2}$ semakin kecil (mendekati nol) maka dapat dikatakan bahwa hubungan variabel bebas $\left(\mathrm{X}_{1}, \mathrm{X}_{2}\right)$ terhadap variabel terikat (Y) semakin kecil. Hal ini berarti model yang digunakan tidak kuat. Secara umum dapat dikatakan besarnya koefisien determinasi berganda $\left(R^{2}\right)$ berada diantara 0 dan 1 atau $0 \leq$ $R^{2} \leq 1$

Hasil koefisien determinasi $\left(R^{2}\right)$ menggunakan SPSS Statistic 20.0 for Windows dapat dilihat pada Tabel 8 dibawah ini :

Tabel 8. Hasil Uji Determinan

\section{Model Summary}

\begin{tabular}{|l|r|r|r|r|}
\hline Model & R & R Square & $\begin{array}{c}\text { Adjusted R } \\
\text { Square }\end{array}$ & $\begin{array}{c}\text { Std. Error of } \\
\text { the Estimate }\end{array}$ \\
\hline 1 & $.771^{\mathrm{a}}$ & .595 & .571 & 1.119 \\
\hline
\end{tabular}
$\begin{aligned} & \text { a. Predictors: (Constant), Motivasi mengajar, Etos kerja, Pengalaman } \\
& \text { mengajar }\end{aligned}$

Berdasarkan Tabel 5.15 diperoleh nilai koefisien determinasi Adjusted $R$ Square sebesar 0,571. Hal ini menunjukan bahwa variabel pengalaman mengajar, etos kerja dan motivasi mengajar memiliki kemampuan menjelaskan pengaruhnya terhadap variabel kinerja guru SMK Negeri 1 Sibolga sebesar $57,1 \%$. Sedangkan sisanya sebesar $42,9 \%$ merupakan pengaruh dari variabel bebas lain yang tidak diteliti dalam penelitian ini. Hasil Adjusted $R$ Square dalam penelitian ini $>0,50$ $(0,571>0,50)$ maka tergolong tinggi ketepatannya dalam memprediksikan besarnya pengaruh variabel-variabel bebas secara bersama-sama (simultan) terhadap variabel terikat.

\section{Evaluasi}

Berdasarkan hasil penelitian yang telah diperoleh dan dianalisis secara statistik mengenai pengaruh pengalaman mengajar, etos kerja dan motivasi mengajar terhadap kinerja guru SMK Negeri 1 Sibolga akan dibahas sebagai berikut :

\subsection{Pengaruh Pengalaman Mengajar Terhadap Kinerja Guru SMK Negeri 1 Sibolga}

Hasil penelitian kepada 55 orang guru SK Negeri 1 Sibolga menunjukkan bahwa pengalaman mengajar mempunyai kontribusi terhadap peningkatan kinerja guru. Dari hasil hipotesis secara parsial (uji t) diperoleh nilai $t_{\text {hitung }}(2,161)>t_{\text {tabel }}(1,675)$ dan tingkat probabilitas sebesar $0,035<0,05$ yang berarti bahwa pengalaman mengajar berpengaruh positif dan signifikan terhadap kinerja guru. 
Berdasarkan analisis regresi variabel pengalaman mengajar memberikan kontribusi hubungan positif terhadap kinerja guru sebesar 0,166 . Artinya semakin baik pengalaman mengajar guru makan kinerja juga akan semakin meningkat.

Berdasarkan analisis deskriptif diketahui bahwa jumlah rata-rata skor dari variabel pengalaman mengajar dalam kriteria sangat baik. Hal ini dilihat dari mayoritas responden memberikan jawaban "sangat setuju" dan "setuju" atas semua pernyataan variabel pengalaman kerja. Pengalaman yang dilalui seseorang guru akan membantu menentukan langkah-langkah tertentu yang dapat menunjang keberhasilan kerja mereka dalam mencapai standar kerja yang telah ditetapkan. Seperti dalam proses pembelajaran guru dituntut agar dapat mengembangkan materi ajar melalui berbagai media dan metode yang bervariatif sehingga membuat siswa menjadi lebih tertarik menelisik lebih lanjut mengenai materi yang diajarkan hingga pada akhirnya mampu mencapai tujuan pembelajaran. Hal ini sesuai apa yang dikemukakan oleh Uno (2013:17) pada dasarnya perubahan perilaku yang dapat ditunjukkan peserta didik dipengaruhi oleh latar belakang pendidikan dan pengalaman yang dimiliki oleh seorang guru. Maka melalui pengalaman mengajar membantu guru dalam mencapai standar kompetensi profesional guru yang harus dipenuhi sesuai dengan hasil penelitian yang dipaparkan diatas.

Hasil penelititan lapangan menunjukkan latar belakang pendidikan guru SMK Negeri 1 Sibolga dalam kriteria baik. Para guru SMK Negeri 1 Sibolga hampir seluruhnya memiliki latar belakang pendidikan S1 bahkan beberapa guru telah menempuh jenjang S2 yang linier dengan bidang studi yang mereka ajarkan. Akan tetapi data hasil penelitian di lapangan masih ditemukan guru yang background pendidikannya yang tidak sesuai dengan mata pelajaran yang diampu. Berdasarkan klasifikasi lama mengajar terkait dengan variabel pengalaman mengajar mayoritas guru SMK Negeri 1 Sibolga memiliki pengalaman mengajar lebih dari 10 tahun. Akan tetapi guru junior tidak kalah baik kemampuan analitis dan keterampilannya dibandingkan dengan guru senior.

Standar kompetensi profesional mengharuskan guru menguasai bahan yang akan diajarkannnya. Sehingga latar belakang guru tersebut menjadi hal yang penting dan berpengaruh, agar guru dapat melaksanakan tanggung jawab profesinya secara kompeten. Oleh karena itu guru dituntut menguasai apa yang mereka ajarkan. Tidak sepantasnya jika ada peserta didik yang lebih luas dalam mendalami keahlian atau bidang studi yang dipelajarinya.

Pengalaman mengajar akan dapat memberikan keuntungan bagi seseorang guru dalam melaksanakan tugas mengajar selanjutnya karena setidaknya guru tersebut sudah pernah melakukan pekerjaan itu sehingga ia akan tahu tentang pekerjaan yang akan dihadapi. Setiap pengalaman yang diperoleh seseorang guru akan membantunya memberikan keterampilan dan pengetahuan khusus sesuai dengan pekerjaan yang digelutinya. Seseorang yang melakukan jenis pekerjaan tertentu secara berulang-ulang dalam jangka waktu yang cukup lama akan menjadikan dirinya cukup terampil dalam pekerjaan tersebut. Hal tersebut sesuai dengan teori yang dikemukakan oleh Widoyoko (2015) bahwa pengalaman mengajar pada hakekatnya merupakan rangkuman dari pemahaman seseorang terhadap hal-hal yang dialami dalam mengajar, sehingga hal-hal yang dialami tersebut telah dikuasinya, baik tentang pengetahuan, ketrampilan maupun nilai-nilai yang menyatu padanya.

\subsection{Pengaruh Etos Kerja Terhadap Kinerja Guru SMK Negeri 1 Sibolga}

Berdasarkan hasil penelitian diperoleh nilai $t_{\text {hitung }}(2,225)>t_{\text {tabel }}(1,675)$ dan tingkat probabilitas sebesar $0,031<0,05$ yang berarti bahwa etos kerja berpengaruh positif dan signifikan terhadap kinerja guru SMK Negeri 1 Sibolga. Berdasarkan analisis regresi variabel ini memberikan kontribusi hubungan positif terhadap kinerja guru sebesar 0,150 . Hal ini menunjukkan bahwa variabel etos kerja ikut berkontribusi dalam peningkatan kinerja guru. Semakin baik etos kerja guru, maka akan meningkatkan kinerja guru tersebut.

Melalui etos kerja guru akan terus bergerak menuju kualitas kerja yang baik sebagaimana yang dipersyaratkan profesinya. Sesuai dengan teori yang dikemukakan oleh Sinamo (2015:249) etos kerja adalah syarat utama bagi semua upaya peningkatan kualitas tenaga kerja atau SDM, baik pada level individual, organisasional, maupun sosial. Guru yang memiliki etos kerja yang lebih baik dari lainnya akan lebih mampu meningkatkan kompetensi profesionalnya sebagai tuntutan atas profesinya 
selain itu juga sebagai bentuk tanggung jawab atas instansi atau sekolah tempat guru bekerja.

Berdasarkan analisis deskriptif diketahui bahwa rata-rata skor dari variabel etos kerja guru SMK Negeri 1 Sibolga termasuk dalam kriteria baik. Pengukuran variabel ini menggunakan lima indikator yaitu : (1) menjadi guru adalah amanah; (2) menjadi guru adalah aktualisasi; (3) menjadi guru adalah seni; (4) menjadi guru adalah kehormatan; dan (5) menjadi guru adalah pelayanan. Hasil analisis deskriptif menunjukkan bahwa mayoritas responden memberikan tanggapan "sangat setuju" dan "setuju" atas semua pernyataan indikator etos kerja. Guru tidak hanya senantiasa berusaha mengembangkan potensi diri, melalui etos kerja guru juga mampu mengubah potensi diri dalam bentuk kompetensi yang dipersyaratkan dalam profesinya. Ini menunjukkan bahwa guru telah bekerja dengan penuh semangat dalam menjalankan tugas mengajarnya.

Hasil pengamatan dilapangan terhadap guru SMK Negeri 1 Sibolga menunjukkan guru sudah memanfaatkan sarana-prasarana yang ada disekolah tetapi belum mengembangkan atau mencari trobosan penunjang pembelajaran sendiri. Para guru tersebut belum mencoba mencari alternatif media lain sebagai pendukung pembelajaran sehingga pembelajaran menjadi lebih menarik. Padahal jika guru menggunakan alternatif lain dalam menyampaikan materi ajar yang dikemas secara lebih menarik akan mempermudah siswa dalam memahami pelajaran yang disampaikan. Maka guru harus senantiasa meningkatkan etos kerjanya agar lebih semangat dalam menjalankan kompetensi profesionalnya. Hal ini didukung dengan teori yang diungkapkan oleh Tasmara (2012:24) “.... etos kerja berkaitan dengan semangat, kejujuran dan kepawaian dalam bidangnya (profesional)".

Hasil penelitian ini sejalan dengan penelitian yang dilakukan oleh Kartini (2011) menyimpulkan bahwa dari delapan faktor yang diteliti faktor yang signifikan mempengaruhi kompetensi guru yaitu faktor etos kerja sebesar. Selain itu penelitian Hasil penelitian Widoyoko (2015) juga menunjukkan bahwa etos kerja memberikan sumbangan positif terhadap kompetensi mengajar guru IPS SMA Kabupaten Purworejo. Dengan demikian penelitian ini dapat diterima karena sesuai dengan teori yang telah ada.

\subsection{Pengaruh Motivasi Mengajar Terhadap Kinerja Guru SMK Negeri 1 Sibolga}

Berdasarkan hasil penelitian diperoleh nilai $t_{\text {hitung }}(6,341)>t_{\text {tabel }}(1,675)$ dan tingkat probabilitas sebesar $0,000<0,05$ yang berarti bahwa motivasi mengajar berpengaruh positif dan signifikan terhadap kinerja guru SMK Negeri 1 Sibolga. Berdasarkan analisis regresi variabel ini memberikan kontribusi hubungan positif terhadap kinerja guru sebesar 0,715. Variabel motivasi mengajar memberikan pengaruh dominan daripada variabel pengalaman mengajar dan etos kerja. Hal ini menunjukkan bahwa variabel motivasi mengajar paling besar berkontribusi dalam peningkatan kinerja guru. Semakin tinggi motivasi mengajar, maka akan meningkatkan kinerja guru tersebut.

Berdasarkan analisis deskriptif diketahui bahwa rata-rata skor dari variabel mengajar guru SMK Negeri 1 Sibolga termasuk dalam kriteria baik. Pengukuran variabel ini menggunakan lima indikator yaitu : (1)

Dorongan mencapai tujuan, (2) Semangat kerja, (3) Kompetensi, dan (4) Rasa tanggungjawab. Hasil analisis deskriptif menunjukkan bahwa mayoritas responden memberikan tanggapan "sangat setuju" dan "setuju" atas semua pernyataan indikator motivasi mengajar.

Hasil pengamatan dilapangan terhadap guru SMK Negeri 1 Sibolga menunjukkan bahwa guru memiliki motivasi yang tinggi. Hal ini terlihat dari semangat para guru dalam melaksanakan tugas pembelajaran di kelas dan keaktifan para guru dalam kegiatan-kegiatan intra kurikuler maupun ekstra kurikuler sekolah. Hasil penelitian ini didukung teori yang dikemukakan Uno (2013:71) bahwa motivasi kerja bagi seorang guru biasanya akan tercermin dalam berbagai kegiatan dan bahkan prestasi yang dicapai. Motivasi kerja guru tidak lain adalah suatu proses yang dilakukan untuk menggerakkan guru agar perilaku mereka dapat diarahkan pada upaya-upaya yang nyata untuk mencapai tujuan yang ditetapkan.

Motivasi kerja merupakan salah satu faktor yang turut menentukan kinerja seseorang. Menurut Uno (2013:72) menyebutkan bahwa motivasi kerja adalah dorongan dari dalam dan luar diri seseorang untuk melakukan sesuatu, yang terlibat dari dimensi internal dan dimensi eksternal. Dimensi internal merupakan suatu dimensi yang berasal dari dalam diri individu tersebut, sedangkan dimensi eksternal 
merupakan lingkungan luar yang melingkupi individu tersebut. Hasil penelitian ini juga sejalan dengan penelitian Iskandar (2012) yang menyimpulkan bahwa motivasi guru berpengaruh terhadap kinerja guru.

\subsection{Pengaruh Pengalaman Mengajar, Etos Kerja dan Motivasi Mengajar Terhadap Kinerja Guru SMK Negeri 1 Sibolga}

Dari hasil hipotesis secara simultan (Uji F) diperoleh nilai $F_{\text {hitung }}(24,977)>F_{\text {tabel }}(2,786)$ dan probabilitas $0,000<0,05$. Sehingga dapat diketahui bahwa terdapat pengalaman mengajar, etos kerja dan motivasi mengajar berpengaruh positif dan signifikan terhadap kinerja guru SMK Negeri 1 Sibolga. Sedangkan hasil uji determinan diperoleh nilai Adjusted $R$ Square sebesar 0,571. Dengan demikian menunjukkan bahwa secara simultan pengaruh pengalaman mengajar, etos kerja dan motivasi mengajar mampu menjelaskan pengaruhnya terhadap kinerja guru sebesar $57,1 \%$, sedangkan sisanya $42,9 \%$ dijelaskan oleh variabel lain yang tidak dikaji dalam penelitian ini.

Terbuktinya hipotesis yang diajukan dalam penelitian ini dapat memberikan informasi bahwa pengalaman mengajar, etos kerja dan motivasi mengajar ikut serta berperan dalam meningkatkan kinerja guru. Sehingga apabila pengalaman mengajar, etos kerja dan motivasi mengajar baik maka kinerja guru juga baik. Begitu pula sebaliknya jika pengalaman mengajar, etos kerja dan motivasi guru kurang baik maka kinerja guru juga kurang baik.

Berdasarkan penelitian tersebut guru perlu meningkatkan pengetahuan, informasi dan keterampilan sebagai bentuk upaya peningkatan pengalaman mengajar. Selain itu, guru perlu meningkatkan etos kerjanya agar kompetensi profesionalnya juga meningkat. Para guru juga diharapkan tetap menjaga semangat dan motivasi dalam bekerja. Motivasi guru dalam bekerja akan menjadi pendorong untuk melaksanakan tugas pembelajaran dengan jujur dan penuh tanggungjawab. Melalui hal tersebut guru dapat lebih kompeten dalam menjalankan tugasnya, salah satunya yaitu tercapainya standar kompetensi profesional yang menjadi fokus penelitian ini. Sesuai dengan teori yang dipaparkan oleh Surya (2014:38) salah satu ciri profil guru yang diperkirakan sesuai dengan tuntutan masa depan menghadapi abad 21 adalah guru yang memiliki etos kerja yang kuat. Dengan pengalaman, etos kerja dan motivasi yang baik guru memiliki sikap atau pandangan mendasar yang mampu mencapai kualitas kerja yang baik seperti kompetensi profesional guru sebagai standar kerja yang harus dipenuhi.

\section{Kesimpulan}

Dari hasil analisis dan evaluasi yang telah diuraikan pada bab sebelumnya, maka dapat ditarik kesimpulan dari penelitian ini adalah :

1) Pengalaman mengajar berpengaruh positif dan signifikan terhadap kinerja guru SMK Negeri 1 Sibolga, dimana nilai $t_{\text {hitung }}(2,161)$ $>\mathrm{t}_{\text {tabel }}(1,675)$ dan tingkat probabilitas sebesar $0,035<0,05$.

2) Etos kerja berpengaruh positif dan signifikan terhadap kinerja guru SMK Negeri 1 Sibolga, dimana diperoleh nilai $t_{\text {hitung }}(2,225)$ $>t_{\text {tabel }}(1,675)$ dan tingkat probabilitas sebesar $0,031<0,05$.

3) Motivasi mengajar berpengaruh positif dan signifikan terhadap kinerja guru SMK Negeri 1 Sibolga, dimana diperoleh nilai $t_{\text {hitung }}(6,341)>t_{\text {tabel }}(1,675)$ dan tingkat probabilitas sebesar $0,000<0,05$.

4) Pengalamana mengajar, etos kerja dan motivasi mengajar berpengaruh positif dan signifikan terhadap kinerja guru SMK Negeri 1 Sibolga, dimana diperoleh nilai $\mathrm{F}_{\text {hitung }}(24,977)>\mathrm{F}_{\text {tabel }}(2,786)$ dan probabilitas $0,000<0,05$. Pengalaman mengajar, etos kerja dan motivasi mengajar mampu menjelaskan pengaruhnya terhadap kinerja guru sebesar $57,1 \%$, sedangkan sisanya $42,9 \%$ dijelaskan oleh variabel lain yang tidak dikaji dalam penelitian ini.

\section{DAFTAR PUSTAKA}

Agung, Iskandar. (2012). Menghasilkan Guru Kompeten dan Profesional. Jakarta : Bee Media Indonesia.

Anoraga, Pandji, 2011. Manajemen Bisnis. Jakarta: Rineka Cipta. Atmodiwirio, Soebagio, 2005. Manajemen Pendidikan Indonesia. Jakarta: Ardadizya Jaya.

Arikunto, Suharsimi. (2014). Prosedur Penelitian Suatu Pendekatan Praktik. Jakarta : Rineka Cipta.

Aulia, Nida. (2015). "Pengaruh Pengalaman Mengajar dan Etos Kerja Terhadap Kompetensi Profesional Guru Produktif Pemasaran Smk Bisnis dan Manajemen di Kota Semarang". Skripsi. Semarang : Unnes. 
Djamrah, Syaiful Bahri, dan Aswin Zain. (2011). Strategi Belajar Mengajar. Jakarta : Rineka Cipta.

Dimyati, dan Mudjiono, (2013), Belajar dan Pembelajaran. Jakarta : Rineka Cipta.

Eliyanto dan Wibowo. (2013). "Pengaruh Pendidikan, Pelatiahan dan Pengalaman Mengajar Terhadap Profesionalisme Guru SMA Muhammadiyah di Kabupaten Kebumen". Tesis. Universitas Negeri Yogyakarta.

Fattah, Nanang. (2012). Landasan Manajemen Pendidikan. Bandung : PT Remaja Rosdakarya.

Ghozali, Imam. (2013). Aplikasi Analisis Multivariate Dengan Program IBM SPSS 2. Semarang : Badan Penerbit Universitas Diponegoro.

Hamalik, Oemar. (2013). Proses Belajar Mengajaran. Jakarta : PT.Bumi Aksara.

Handoko, T.Hani. (2013). Manajemen Personalia dan Sumberdaya Manusia. Yogyakarta : BPFE.

Harlie. M, 2010. Pengaruh Disiplin kerja, Motivasi dan Pengembangan Karier terhadap Kinerja pegawai Negeri Sipil Pada Pemerintah Kabupaten Tabalong Di Tanjung Kalimantan Selatan. Jurnal Manajemen dan Akuntansi. Vol : 11. No : 2.

Iskandar, 2012. Pengaruh Motivasi dan Lingkungan Kerja Terhadap Kinerja Guru SMA Negeri Se-Kabupaten Kendal. Educational Management Journal. Vol: 1. No: 2.

Iskandar, Dadang dan Narsim. (2015). Penelitian Tindakan Kelas dan Publikasinya. Cilacap : Ihya Media.

Kartini, Titin. (2011). "Faktor-Faktor Yang Mempengaruhi Kompetensi Profesional Guru Di SMK Negeri 1 Losarang Kabupaten Indramayu". Jakarta : Universitas Indonesia.

Masruroh, Umi., Thomas, P., dan Latifah,L., 2012. Pengaruh Kompensasi dan Disiplin Kerja Terhadap Kinerja Guru Ekonomi SMA Negeri Brebes. Economic Education Analysis Journal. Vol: 1. No: 2.

Mathis, Robert L, dan John H. Jackson. (2012). Manajemen Sumber Daya Manusia, Buku Satu, Edisi Indonesia. Jakarta : PT Salemba Empat.

Mulyana. (2012). Rahasia Menjadi Guru Hebat. Surabaya : Grasindo.
Muslich, Masnur. (2016). Sertifikasi Guru Menuju Profesionalisme Pendidik. Jakarta : Bumi Aksara

Ndara, Talizduhu. (2012). Pengantar Teori Pengembangan Sumber Daya Manusia. Jakarta : PT. Rineka Cipta.

Purwanto, Ngalim. (2012). Prinsip-Prinsip dan Teknik Evaluasi Pengajaran. Bandung : PT. Remaja Rosdakarya.

Robbins, Stephan. (2014). Perilaku Organisasi : Konsep, Kontroversi dan Aplikasi. Alih Bahasa Handayani Pujaatmika. Edisi Bahasa Indonesia, Jakarta : Prenhalindo.

Sastrohadiwiryo, Suwanto. (2013). Manajemen Tenaga Kerja Indonesia, edisi. 2. Jakarta : Bumi Aksara.

Sardiman. (2014). Interaksi dan Motivasi Belajar Mengajar. Jakarta : Rajawali Press.

Sedarmayanti. (2013). Sumber Daya Manusia dan Produktivitas Kerja. Bandung : Mandar Maju.

Slavin, Robert E. (2015). Cooperative Learning. Bandung : Nusa Media.

Sinamo, Jansen H. (2015). Delapan Etos Kerja Profesional. Jakarta : Institut Darma Mahardika.

Sudjana, Nana. (2013). Dasar-Dasar Proses Belajar Mengajar. Bandung : Sinar Baru Algensindo.

Sugiyono. (2016). Metode Penelitian Bisnis. Bandung : CV Alfabeta.

Sujanto, Bedjo. (2011). Guru Indonesia Dan Perubahan Kurikulum : Mengorek Kegelisahan Guru. Jakarta : CV. Sagung Set.

Sunyoto, Danang. (2016). Analisis Regresi dan Uji Hipotesis. Jakarta : PT. Buku Seru.

Supeno, Hadi. (2011). Potret Guru. Jakarta : Pustaka Sinar Harapan.

Surya, Muhammad. (2014). Bunga Rampai Guru dan Pendidikan. Jakarta : Balai Pustaka

Suryanto, A. (2011). Pengaruh Pengaruh Pemberian Tunjangan Profesional Guru Terhadap Peningkatan Kinerja Guru Jenjang SMA Rintisan Sekolah Berstandar Internasional Kota Yogyakarta.

Syauqi, Ahmad. (2019). "Pengaruh Koordinasi dan Disiplin Kerja Terhadap Kinerja Pegawai Sekretariat Kota Administrasi Jakarta Selatan". Jurnal Renaissance, Volume 4 No. 02 Agustus 2019, hlm: 551559.

Tasmara, Toto. (2012). Membudayakan Etos Kerja Islami. Jakarta : Gema Insani Press. 
Unal, Zafer dan Aslihan. (2012). The Impact Of Teaching Experience On The Classroom Management Approaches Of Elementary School Teachers. www.e-iji.net.

Uno, B. Hamzah. (2013). Teori Motivasi dan Pengukurannya. Jakarta : PT Bumi Aksara.

Usman, Uzer. (2014). Menjadi Guru Profesional. Bandung : PT. Remaja Rosdakarya.

Viqraizin, Victy Vidaya. (2015). "Pengaruh Kompetensi Pedagogik Dan Kepuasan Kerja Terhadap Kinerja Guru Sekolah Dasar Se Kecamatan Gondokusuman Yogyakarta". Tesis.Yogyakarta : UNY.

Wibowo. (2014). Manajemen Kinerja. Jakarta: Rajagrafindo Persada.

Widoyoko, Eko Putro S. (2015). Kompetensi Mengajar Guru IPS Kabupaten Purworejo. Dirjen Dikti.

Widyaningsih, Anis. (2014). "Pengaruh Latar Belakang Pendidikan dan Pengalaman Mengajar Terhadap Kompetensi Profesional Guru MA Negeri 1 Surakarta Tahun Ajaran 2013/2014". Universitas Muhammadiyah Surakarta.

Yamin, Martinis dan Maisah. (2011). Standarisasi Kinerja Guru. Jakarta : Persada Press.

Yuliana, Eka. (2012). "Pengaruh Kemampuan Intelektual Dan Motivasi Kerja Terhadap Kinerja Guru Mata Diklat Produktif Penjualan Di Smk Bisnis Dan Manajemen Se-Kabupaten Kebumen". Skripsi. Semarang : Unes. 